\title{
PENGARUH PROFITABILITAS TERHADAP HARGA SAHAM PADA PERUSAHAAN LQ-45 DI BURSA EFEK INDONESIA (BEI)
}

\author{
Ade Indah Wulandari ${ }^{1}$ \\ Ida Bagus Badjra ${ }^{2}$ \\ ${ }^{1,2}$ Fakultas Ekonomi dan Bisnis Universitas Udayana, Bali, Indonesia \\ email: ade.indahwulandari@yahoo.com
}

\begin{abstract}
ABSTRAK
Harga saham merupakan harga di pasar bursa pada saat tertentu yang ditentukan oleh pelaku pasar dan ditentukan oleh permintaan dan penawaran saham yang bersangkutan di pasar modal. Harga saham mencerminkan nilai perusahaan dan efektivitas perusahaan. Harga saham semakin tinggi, maka nilai perusahaan semakin tinggi. Penelitian ini dilakukan untuk menguji pengaruh profitabilitas terhadap harga saham pada perusahaan LQ-45 di Bursa Efek Indonesia (BEI). Jumlah sampel yang diteliti sebanyak dua puluh tujuh (27) perusahaan yang dipilih melalui metode sampling jenuh dengan periode pengamatan selama empat tahun. Metode pengumpulan data yang digunakan dalam penelitian ini adalah dengan metode observasi nonpartisipan. Analisis data dilakukan dengan teknik analisis model regresi linier berganda. Berdasarkan hasil analisis ditemukan bahwa Return On Equity dan Net Profit Margin memiliki pengaruh positif signifikan terhadap harga saham, sedangkan Return On Assets berpengaruh tidak signifikan terhadap harga saham. Kenaikan ROE dan NPM akan diikuti dengan kenaikan harga saham.

Kata kunci: harga saham, return on assets, return on equity, net profit margin
\end{abstract}

\begin{abstract}
The stock price is the price on the stock market at a certain time determined by market participants and is determined by the demand and supply of the shares in question in the capital market. The stock price reflects the value of the company and the effectiveness of the company. The stock price is getting higher, the higher the company's value. This research was conducted to examine the effect of profitability on stock prices in LQ-45 companies on the Indonesia Stock Exchange (IDX). The number of samples studied were twenty-seven (27) companies selected through a saturated sampling method with a fouryear observation period. The data collection method used in this study is a nonparticipant observation method. Data analysis was carried out by multiple linear regression model analysis techniques. Based on the results of the analysis it was found that Return On Equity and Net Profit Margin had a significant positive effect on stock prices, while Return On Assets had no significant effect on stock prices. The increase in ROE and NPM will be followed by an increase in stock prices.
\end{abstract}

Keywords: stock price, return on assets, return on equity, net profit margin 


\section{PENDAHULUAN}

Harga saham merupakan faktor yang sangat penting untuk diperhatikan dan indikator digunakan untuk mengukur kesejahteraan pemegang saham. Hartono (2016: p. 180) menyatakan nilai perusahaan ditunjukkan dengan harga saham dan sebagai pengukur efektivitas perusahaan. Semakin tinggi harga saham, maka semakin tinggi nilai perusahaan tersebut dan begitu pula sebaliknya. Saham yang rendah dapat diartikan bahwa kinerja perusahaan tidak maksimal, namun bila harga saham tinggi dapat mengurangi kemampuan para investor untuk membeli saham tersebut.

Indeks pasar saham merupakan ringkasan informasi kinerja pasar saham dalam suatu indeks. Indeks pasar saham adalah indikator yang menunjukkan kinerja saham-saham di pasar. Indeks pasar saham juga disebut indeks harga saham karena merupakan indikator yang menggambarkan pergerakan harga-harga saham. Bursa Efek Indonesia terdiri dari sebelas indeks, yaitu indeks individual, indeks harga saham sektoral, indeks harga saham gabungan (IHSG), indeks LQ45, indeks syariah, indeks papan utama, indeks papan pengembangan, indeks kompas 100, indeks BISNIS-27, indeks PEFINDO25, indeks SRI-KEHATI.

Intensitas transaksi berbeda-beda setiap sekuritas di pasar modal. LQ-45 merupakan 45 saham di BEI yang memiliki likuiditas tertinggi, memiliki kapitalisasi pasar terbesar dan lolos seleksi melalui beberapa kriteria. Tahun 2014 harga saham pada level Rp. 898,581. Tahun 2015 mengalami penurunan yaitu pada level Rp. 792,033 dengan tingkat penurunan 13,45 persen (\%). Selama tahun 2016 dan 2017 meningkat hingga di atas harga Rp. 1.079,39 dengan kenaikan pada tahun 2016 sebesar 10,47 persen (\%) dan pada tahun 2017 sebesar 18,04 persen $(\%)$.

Investor harus memiliki informasi terkait mengenai fluktuasi harga saham guna untuk pengambilan keputusan mengenai saham perusahaan yang dapat dikatakan layak untuk dipilih. Pentingnya informasi yang akurat mengenai kinerja keuangan suatu perusahaan, kondisi ekonomi makro, manajemen perusahaan, dan informasi lainnya. Proses pengambilan keputusan tergantung dari faktor fundamental perusahaan. Penilaian saham bertujuan untuk meminimalkan risiko dalam mendapatkan keuntungan, karena investasi saham memiliki risiko tinggi tetapi menjanjikan keuntungan yang besar.

Menurut Hartono (2016: p. 188) analisis yang banyak digunakan untuk menentukan nilai sebenarnya dari saham terdapat dua jenis yaitu analisis fundamental dan analisis teknikal. Analisis fundamental menggunakan data yang berasal dari keuangan perusahaan. Analisis teknikal menggunakan data pasar dari saham seperti harga dan volume transaksi saham untuk menentukan nilai dari saham. Analisis teknikal sering digunakan oleh praktisi dalam menentukan harga saham. Analisis fundamental sering digunakan oleh akademisi.

Meskipun analisis teknikal paling sering digunakan menentukan harga saham, tetapi analisis fundamental juga diperhatikan karena investor dalam memilih investasi saham juga akan melihat laporan keuangan perusahaan, dari laporan keuangan perusahaan dapat diperkirakan keadaan dan posisi perusahaan. Analisis fundamental digunakan untuk menghitung nilai intrinsik dari suatu saham dengan menggunakan data atau rasio-rasio keuangan perusahaan. 
Petunjuk yang menuntun manajemen perusahaan untuk menetapkan target dan standar ditunjukan dengan rasio keuangan. Rasio keuangan membantu manajer keuangan dalam menetapkan strategi jangka panjang maupun keputusan jangka pendek yang efektif. Rasio keuangan perusahaan terdiri dari 5 (lima) bagian, yaitu: rasio leverage dimana mengukur sejauh mana perusahaan dibiayai dari dana pinjaman, rasio likuiditas yang dimana mengukur kemampuan perusahaan untuk memenuhi kewajiban jangka pendek, rasio aktivitas yang dimana mengukur efektifitas perusahaan dalam memanfaatkan sumber dananya, rasio profitabilitas yang dimana mengukur kemampuan perusahaan untuk menghasilkan laba, dan rasio pasar yang dimana mengukur pengakuan pasar terhadap kondisi keuangan perusahaan (Wiagustini, 2014: p. 84).

Profitabilitas mencerminkan kemampuan suatu perusahaan dalam memperoleh laba atau dengan kata lain ukuran efektivitas pengelolaan manajemen perusahaan. Kemampuan perusahaan dalam memperoleh laba dapat diukur melalui modal sendiri hingga dari seluruh dana yang diinvestasikan ke dalam perusahaan (Wiagustini, 2014: p. 86). Profitabilitas mampu mengukur sejauh mana kemampuan suatu perusahaan dalam memperoleh laba. Laba merupakan faktor utama mengukur tingkat efektifitas dan efisiensi perusahaan dengan seluruh dana dan sumber daya perusahaan.

Indikator yang digunakan untuk melihat kemampuan perusahaan memperoleh profitabilitas ini ditunjukkan dari beberapa rasio keuangan antara lain: return on assets (ROA), return on equity (ROE), net profit margin (NPM) yang mengukur kemampuan perusahaan menghasilkan laba (Wiagustini, 2014: p. 90).

ROA merupakan rasio yang digunakan untuk mengukur kemampuan perusahaan dalam memperoleh laba yang dimilikinya. Penelitian yang dilakukan oleh Kundiman \& Hakim (2016), Murniati (2016), Manoppo (2015), Purnamasari (2015), Febriyanto \& Nurwiyanta (2014), Amanah, Atmanto \& Azizah (2014), serta Kabajeh, Nu'aimat \& Dahmash (2012) menemukan bahwa ROA berpengaruh positif signifikan terhadap harga saham. Berbeda dengan penelitian yang dilakukan oleh Sahroni, Zulfitra, Sampurnaningsih \& Hanifah (2017) dan Darnita (2013) menemukan ROA berpengaruh negatif signifikan terhadap harga saham. Penelitian yang dilakukan Hutapea, Saerang \& Tulung (2017), Rorong, Saerang \& Untu (2017), Idawati \& Wahyudi (2015), Tamuntuan (2015), Hutabarat \& Flora (2015) serta Haryuningputri \& Widyarti (2012) menemukan hasil yang berbeda bahwa ROA tidak berpengaruh signifikan terhadap harga saham.

ROE merupakan rasio yang digunakan untuk mengukur laba bersih untuk pemegang saham yang dimana dibagi dengan total ekuitas para pemegang saham. Penelitian mengenai variabel ROE pernah dilakukan oleh Kamar (2017), Sahroni et al. (2017), Manoppo (2015), Mussalamah \& Isa (2011), Talamati \& Pangemanan (2015), Purnamasari (2015), Febriyanto \& Nurwiyanta (2014), Hutami (2012) dan Nurfadillah (2011) menemukan hasil bahwa ROE berpengaruh positif signifikan terhadap harga saham. Hasil yang berbeda ditemukan oleh Rahmadewi \& Abundanti (2018), Murniati (2016), (Rimbani, 2016) dan Darnita (2013) bahwa berpengaruh negatif signifikan terhadap harga saham. Lain halnya 
dalam penelitian yang ditemukan Noor \& Rosyid (2018), Rorong et al. (2017), Mogonta \& Pandowo (2016), Kundiman \& Hakim (2016), Tamuntuan (2015), Hunjra, Ijaz, Chani, Hassan dan Mustafa (2014), Amanah et al. (2014), Hutabarat \& Flora (2015), Perdana, Darminto \& Sudjana (2013), Haryuningputri \& Widyarti (2012) serta Kabajeh et al. (2012) bahwa ROE tidak berpengaruh signifikan terhadap harga saham.

NPM yaitu rasio yang menunjukkan kemampuan perusahaan menghasilkan keuntungan bersih setelah pajak. Penelitian Anggadini \& Tarsiah (2017), Banchuenvijit (2016), Rimbani (2016), Darnita (2013), serta Hutami (2012) menemukan bahwa NPM berpengaruh positif signifikan terhadap harga saham. Lain halnya dengan hasil penelitian Murniati (2016) berpengaruh negatif signifikan terhadap harga saham. Namun, penelitian yang dilakukan Hutapea et al. (2017) dan Rorong et al. (2017) mengemukakan bahwa NPM tidak berpengaruh signifikan terhadap harga saham.

Adanya fluktuasi harga saham perusahaan LQ-45 serta reset gap penemuan penelitian tentang pengaruh ROA, ROE, dan NPM terhadap harga saham. Menjadi celah untuk dilakukannya penelitian kembali, tujuannya untuk memperjelas temuan penelitian sebelumnya. Berdasarkan penjelasan di atas, maka peneliti tertarik untuk melakukan penelitian dengan judul, "Pengaruh Profitabilitas Terhadap Harga Saham pada Perusahaan LQ-45 di Bursa Efek Indonesia (BEI)".

Teori sinyal merupakan tindakan manajemen suatu perusahaan memberikan indikasi pada investor mengenai bagaimana manajemen dalam menilai prospek pada perusahaan tersebut. Perusahaan dengan masa depan yang cerah akan lebih memilih tidak melakukan pendanaan dalam penawaran saham baru, sedangkan perusahaan dengan masa depan yang buruk menyukai pendanaan dalam ekuitas luar (Brigham \& Houston, 2011: p. 186). Teori sinyal digunakan untuk menjelaskan bahwa pada dasarnya laporan keuangan dimanfaatkan perusahaan untuk memberi sinyal positif maupun negatif kepada pemakainya.

Laporan tahunan menjadi informasi yang dikeluarkan perusahaan dan akan menjadi signal bagi pihak di luar perusahaan. Informasi yang terkandung dalam laporan tahunan terdiri dari informasi akuntansi yang berkaitan dengan laporan keuangan dan informasi yang tidak berkaitan dengan laporan keuangan. Perusahaan perlu melakukan pengungkapan laporan keuangan secara terbuka dan transparan agar sahamnya dibeli oleh investor.

Harga saham adalah harga yang terlihat di pasar bursa pada saat tertentu yang ditentukan oleh pelaku pasar dan ditentukan oleh permintaan dan penawaran saham yang bersangkutan di pasar modal (Hartono, 2009: p. 143). Bagi investor, harga saham merupakan indikator untuk mengukur kesejahteraan pemegang saham. Naik turunnya harga saham di pasar modal akan berpengaruh juga terhadap naik turunnya nilai suatu perusahaan.

Kekayaan pemegang saham ditentukan oleh harga saham. Maksimalisasi harga saham perusahaan dengan kata lain memaksimalkan kekayaan pemegang saham. Harga saham ditentukan oleh arus kas yang diinginkan diterima di masa depan oleh investor jika investor membeli saham tersebut (Brigham dan Houston, 2010: p. 7). 
ROA yaitu rasio untuk mengukur kemampuan perusahaan memperoleh laba dari aset yang dimilikinya. Rasio ini mencerminkan keefisienan perusahaan mengelola aktiva dalam memperoleh pendapatan. Semakin besar nilai ROA, menunjukkan kinerja perusahaan yang semakin baik pula. Untuk menghasilkan ROA yang tinggi, perusahaan dituntut untuk mengalokasikan investasinya pada aset yang lebih menguntungkan (Tandelilin, 2010: p. 80).

ROA yang positif mencerminkan pengelolaan aset perusahaan yang efisien, sehingga perusahaan akan menghasilkan laba perusahaan semakin besar. Laba yang tinggi menyebabkan permintaan terhadap saham juga tinggi, yang akan diikuti dengan kenaikan harga saham. ROA memiliki hubungan positif terhadap harga saham (Darmadji, 2006: p. 6).

Penelitian yang dilakukan oleh Kundiman \& Hakim (2016), Murniati (2016), Manoppo (2015), Purnamasari (2015), Febriyanto \& Nurwiyanta (2014), Amanah et al. (2014), serta Kabajeh et al. (2012) menemukan bahwa ROA berpengaruh positif signifikan terhadap harga saham. Berdasarkan uraian diatas dapat dirumuskan hipotesis sebagai berikut:

$\mathrm{H}_{1}$ : Return on assets (ROA) berpengaruh positif dan signifikan terhadap Harga Saham

ROE yaitu laba bersih para pemegang saham yang dibagi dengan total ekuitas dari para pemegang saham. Para pemegang saham ingin memperoleh tingkat pengembalian tinggi, dan ROE menunjukkan tingkat pengembalian yang mereka akan terima. ROE tinggi, maka harga saham juga akan tinggi dan peningkatan ROE akan meningkatkan harga saham (Brigham dan Houston, 2010: p. 133).

Menurut (Kasmir, 2012: p. 77) ROE memiliki pengaruh positif pada harga saham. Ketika ROE naik maka harga saham juga akan naik karena investor melihat manajemen mengelola aktivanya untuk menjadi laba sehingga investor tertarik untuk menginvestasikan dananya pada perusahaan, ROE yang tinggi sehingga akan meningkatkan permintaan terhadap saham dan kenaikan pada harga saham.

Penelitian mengenai variabel ROE pernah dilakukan oleh Sahroni et al. (2017), Kamar (2017), Manoppo (2015), Mussalamah \& Isa (2011), Talamati \& Pangemanan (2015), Purnamasari (2015), Febriyanto \& Nurwiyanta (2014), Hutami (2012) serta Nurfadillah (2011) menemukan hasil bahwa ROE berpengaruh positif signifikan terhadap harga saham. Berdasarkan penjelasan diatas dapat dirumuskan hipotesis sebagai berikut:

$\mathrm{H}_{2}$ : Return on equity (ROE) berpengaruh positif dan signifikan terhadap Harga Saham

NPM yaitu rasio yang digunakan untuk menunjukkan kemampuan suatu perusahaan menghasilkan laba bersih setelah pajak. NPM yaitu perbandingan antara laba bersih dengan penjualan. Semakin tingg NPM, berarti semakin produktif perusahaan sehingga akan meningkatkan kepercayaan dari investor. Melalui hal tersebut, investor akan dapat menilai profitable perusahaan (May, 2011: p. 35) NPM berpengaruh positif terhadap harga saham (Kasmir, 2012: p. 
77). Semakin tinggi nilai NPM maka akan semakin tinggi pula harga saham dan sebaliknya semakin rendah nilai NPM maka harga saham juga akan semakin rendah. Dapat dikatakan juga semakin tinggi nilai NPM semakin efisien perusahaan tersebut mendapatkan laba dari penjualan. Hal itu juga menunjukkan bahwa perusahaan mampu menekan biaya-biaya dengan baik.

Penelitian Anggadini \& Tarsiah (2017), Rimbani (2016), Banchuenvijit (2016), Darnita (2013), serta Hutami (2012) menemukan bahwa NPM berpengaruh positif signifikan terhadap harga saham. Berdasarkan uraian diatas dapat dirumuskan hipotesis sebagai berikut:

$\mathrm{H}_{3}$ : Net profit margin (NPM) berpengaruh positif dan signifikan terhadap Harga Saham

\section{METODE PENELITIAN}

Desain penelitian yang digunakan adalah penelitian yang bersifat asosiatif dan menggunakan pendekatan kuantitatif. Asosiatif yaitu penelitian yang bertujuan untuk mengetahui hubungan antara satu atau lebih variabel terhadap variabel lain. Penelitian ini dilakukan pada perusahaan LQ-45 periode 2014-2017. Obyek pada penelitian ini adalah harga saham pada perusahaan LQ-45 periode 2014-2017. Variabel bebas penelitian ini adalah ROA $\left(\mathrm{X}_{1}\right)$, ROE $\left(\mathrm{X}_{2}\right)$, dan NPM $\left(\mathrm{X}_{3}\right)$. Variabel terikat penelitian ini adalah harga saham $(\mathrm{Y})$. Harga saham yang digunakan adalah harga penutupan saham (closing price) pada masing-masing perusahaan LQ-45 yang diperoleh dari harga saham pada periode akhir tahun selama periode 2014-2017.

ROA dihitung dengan perbandingan antara laba bersih dengan total aktiva yang dinyatakan dalam satuan persentase (\%) pada masing-masing perusahaan LQ-45 periode 2014-2017. Rumus perhitungan ROA menurut (Wiagustini, 2014: p. 90) sebagai berikut:

ROA $=\frac{\text { Laba Bersih }}{\text { Total Aktiva }} \times 100 \%$

ROE dihitung dengan perbandingan antara laba bersih setelah pajak yang dinyatakan dalam satuan persentase (\%) pada masing-masing perusahaan LQ-45 periode 2014-2017. Rumus untuk menghitung ROE adalah sebagai berikut (Wiagustini, 2014: p. 90):

$$
\mathrm{ROE}=\frac{\text { Laba Bersih }}{\text { Modal Sendiri }} \times 100 \%
$$

NPM dihitung dengan perbandingan antara laba bersih dengan penjualan yang dapat dinyatakan dengan satuan persentase (\%) pada masing-masing perusahaan LQ-45 periode 2014-2017. Rumus untuk menghitung NPM adalah sebagai berikut (Wiagustini, 2014: p. 90): 
NPM $=\frac{\text { Laba Bersih }}{\text { Penjualan }} \times 100 \%$

Populasi adalah wilayah generalisasi yang terdiri atas objek dan subjek yang mempunyai kualitas dan karakteristik tertentu yang ditetapkan oleh peneliti untuk dipelajari dan kemudian menyimpulkannya (Rahyuda, 2017: p. 117). Populasi dalam penelitian ini adalah perusahaan LQ-45 yang memiliki laba selama periode 2014-2017. Berdasarkan pengamatan jumlah populasi dalam penelitian ini adalah 27 perusahaan. Penelitian menggunakan metode sampling jenuh yang merupakan teknik pengambilan sampel dengan mengambil semua anggota populasi sebagai sampel (Sugiyono, 2013: p. 96). Jumlah sampel penelitian adalah 27 perusahaan.

Metode pengumpulan data yang digunakan pada penelitian ini adalah metode observasi non partisipan. Jenis data yang digunakan dalam penelitian ini adalah data kuantitatif berupa angka yang terdapat dalam laporan keuangan perusahaan yang terdaftar di LQ-45 periode 2014-2017. Sumber data yang digunakan dalam penelitian ini adalah sumber data sekunder yang diambil dari laporan keuangan perusahaan yang diakses pada LQ-45 melalui situs resmi BEI.

Analisis dalam penelitian ini diolah menggunakan program Statistical Package for Social Science (SPSS). Agar diperoleh hasil model analisis regresi yang dapat dipertanggungjawabkan maka data terlebih dahulu diuji dengan uji asumsi klasik. Pertama, uji normalitas bertujuan menguji apakah pada model regresi, variabel independen dan dependen berdistribusi normal (Ghozali, 2016: $\mathrm{p}$. 160). Uji normalitas merupakan bagian dari uji asumsi klasik. Data penelitian harus diuji distribusi normalnya, data yang baik adalah residual data yang distribusinya normal.

Uji autokorelasi yaitu menguji apakah model regresi terdapat kesalahan pada periode sebelumnya (Ghozali, 2016: p. 110). Model regresi dikatakan baik adalah regresi yang tidak terjadi autokorelasi. Uji autokorelasi dapat dilakukan dengan Durbin-Watson (DW test). Jika $0<\mathrm{d}<\mathrm{dl}$ atau $4-\mathrm{dl}<\mathrm{d}<4$, maka autokorelasi dengan hipotesis nol ditolak. Jika $\mathrm{du}<\mathrm{d}<4-\mathrm{du}$, maka autokorelasi dengan hipotesis nol diterima. Jika $\mathrm{dl} \leq \mathrm{d} \leq \mathrm{du}$ atau $4-\mathrm{du} \leq \mathrm{d} \leq 4-\mathrm{dl}$, maka autokorelasi dengan hipotesis nol tidak ada keputusan.

Uji multikolonieritas yaitu menguji apakah terdapat korelasi antar variabel independen pada model regersi (Ghozali, 2016: p. 105). Model regresi dikatakan baik yaitu tidak terjadi multikolonieritas. Multikolonieritas dilihat dari nilai tolerance dan variance inflation factor (VIF). Jika nilai tolerance $\leq 0,10$ atau VIF $\geq 10$ artinya terdapat multikolonieritas. Nilai tolerance $>0,10$ atau $\mathrm{VIF}<10$ artinya tidak terdapat multikolonieritas.

Uji heteroskedastisitas yaitu menguji apakah terdapat perbedaan varian dari satu pengamatan ke pengamatan lainnya pada model regresi. Model regresi dikatakan baik jika tidak terjadi heteroskedastisitas. Pengujian heteroskedastisitas menggunakan uji glejser. Jika probabilitas memiliki signifikansi di atas tingkat kepercayaan $5 \%$ atau 0,05 artinya model regresi tidak terdapat adanya heteroskedastisitas (Ghozali, 2016: p. 143).

Teknik analisis model regresi linier berganda digunakan untuk menggambarkan hubungan antara variabel terikat dengan variabel bebas yaitu: 
$\mathrm{Y}=\alpha+\mathrm{B}_{1} \mathrm{X}_{1}+\mathrm{B}_{2} \mathrm{X}_{2}+\mathrm{B}_{3} \mathrm{X}_{3}+\mathrm{B}_{4} \mathrm{X}_{4}+\varepsilon$

Keterangan:

$\mathrm{Y}=$ Harga saham

$\alpha=$ Nilai konstanta

$\mathrm{B}_{1}, \mathrm{~B}_{2}, \mathrm{~B}_{3}, \mathrm{~B}_{4}=$ Koefisien regresi variabel independen

$\mathrm{X}_{1}=$ Return On Assets

$\mathrm{X}_{2}=$ Return On Equity

$\mathrm{X}_{3}=$ Net Profit Margin

$\varepsilon=$ Standar eror

Uji statistik F digunakan untuk melihat kelayakan model penelitian. Tujuan dilakukannya uji $\mathrm{F}$ yaitu untuk melihat apakah variabel secara serempak mempengaruhi variabel terikat. Hasil uji $\mathrm{F}$ dapat dilihat pada regresi olahan SPSS dengan cara membandingkan tingkat signifikansi antara variabel bebas $\alpha=0,05$. Apabila tingkat signifikansi $\mathrm{F} \leq \alpha=0,05$ maka variabel bebas secara signifikan mempengaruhi variabel terikat dan model regresi dianggap layak untuk diuji. Sebaliknya, apabila tingkat signifikansi $\mathrm{F} \geq \alpha=0,05$ maka variabel bebas tidak signifikan mempengaruhi variabel terikat (Ghozali, 2016: p. 94).

Koefisien determinasi digunakan untuk mengukur seberapa jauh kemampuan variabel bebas dalam menjelaskan variasi variabel terikat. Nilai koefisien determinasi adalah antara nol dan satu. Bila nilai koefisien determinasi mendekati satu maka variabel bebas memberikan hampir semua informasi yang dibutuhkan untuk memprediksi variabel terikat dan jika nilai koefisien determinasi sama dengan nol $\left(\mathrm{R}^{2}=0\right)$ berarti variabel bebas tidak berpengaruh terhadap variabel terikat (Ghozali, 2016: p. 95).

Uji $\mathrm{t}$ dilakukan untuk menguji secara parsial variabel bebas yang mempengaruhi variabel terikat, dengan asumsi jika nilai signifikansi t hitung $\leq$ 0,05 yang berarti bahwa hubungan antara masing-masing variabel bebas adalah signifikan mempengaruhi variabel terikat. Sebaliknya jika hasil uji t menunjukkan bahwa $t$ hitung $\geq 0,05$ yang berarti bahwa hubungan antara masing-masing variabel bebas tidak signifikan mempengaruhi variabel terikat (Ghozali, 2016: p. 94).

\section{HASIL DAN PEMBAHASAN}

LQ-45 terdiri dari 45 saham yang terpilih melalui beberapa kriterian. Saham LQ-45 meupakan pilihan yang memenuhi kriteria pemilihan sehingga akan terdiri dari saham-saham yang memiliki likuiditas tinggi dan kapitalisasi pasar besar. Saham-saham perusahaan yang dalam penelitian adalah saham LQ-45 yang memiliki laba selama periode 2014-2017. Jumlah saham dalam penelitian ini yaitu 27 perusahaan. 
Tabel 1.

Hasil Analisis Statistik Deskriptif

\begin{tabular}{|c|c|c|c|c|c|c|}
\hline & & $\mathbf{N}$ & Minimum & Maksimum & Mean & Std. Deviation \\
\hline $\mathrm{N}$ & Valid & 96 & & & & \\
\hline Harga Saham & & 96 & 488,00 & 55900,00 & 8351,9063 & 9144,99813 \\
\hline ROA & & 96 & 1,41 & 40,18 & 8,7866 & 7,66249 \\
\hline ROE & & 96 & 2,87 & 135,85 & 19,7494 & 23,75195 \\
\hline NPM & & 96 & 4,28 & 43,37 & 16,8360 & 9,16529 \\
\hline
\end{tabular}

Sumber: Data Sekunder diolah, 2018

Pada Tabel 1. dapat dilihat jumlah pengamatan $(\mathrm{N})$ dari penelitian ini adalah 96. Angka pada kolom minimun dalam tabel menunjukkan nilai terendah dari data variabel penelitian, sedangkan kolom maksimum menunjukkan nilai tertinggi dari data variabel penelitian. Kolom mean menunjukkan rata-rata data dari masingmasing variabel dan kolom standar deviation menunjukkan simpangan baku.

Variabel harga saham mempunyai rentang nilai 488,00 sampai dengan 55900,00 dari 96 data. Nilai terendah sebesar 488,00 dimiliki oleh LPKR pada tahun 2017 dan nilai tertinggi sebesar 55900,00 dimiliki oleh UNVR tahun 2017. Harga saham rata-rata seluruh perusahaan sampel adalah sebesar 8351,9063 dengan simpangan baku sebesar 9144,99813.

Variabel ROA mempunyai rentang nilai 1,41 sampai dengan 40,18 dari 96 data. Nilai terendah sebesar 1,41 dimiliki oleh BMRI pada tahun 2016 dan nilai tertinggi sebesar 40,18 dimiliki oleh UNVR tahun 2014. Harga saham rata-rata seluruh perusahaan sampel adalah sebesar 8,7866 dengan simpangan baku sebesar 7,66249 .

Variabel ROE mempunyai rentang nilai 2,87 sampai dengan 135,85 dari 96 data. Nilai terendah sebesar 2,87 dimiliki oleh LPKR pada tahun 2017 dan nilai tertinggi sebesar 135,85 dimiliki oleh UNVR tahun 2016. Harga saham rata-rata seluruh perusahaan sampel adalah sebesar 19,7494 dengan simpangan baku sebesar 23,75195.

Variabel NPM mempunyai rentang nilai 4,28 sampai dengan 43,37 dari 96 data. Nilai terendah sebesar 4,28 dimiliki oleh PTPP pada tahun 2014 dan nilai tertinggi sebesar 43,37 dimiliki oleh BBCA tahun 2017. Harga saham rata-rata seluruh perusahaan sampel adalah sebesar 16,8360 dengan simpangan baku sebesar 9,16529.

Tabel 2.

Hasil Uji Normalitas

\begin{tabular}{llr}
\hline & & Unstandardized Residual \\
\hline $\mathrm{N}$ & & 96 \\
Normal Parameters a,b & Mean & $-0,2647355$ \\
& Std. Deviation & 0,98390565 \\
Most Extreme & Absolute & 0,138 \\
Differences & Positive & 0,138 \\
& Negative & $-0,100$ \\
Kolmogorov-Smirnov Z & & 1,354 \\
Asymp. Sig. (2-tailed) & & 0,051 \\
\hline Sumber: Data Sekunder diolah, 2018 &
\end{tabular}


Hasil analisis yang disajikan pada Tabel 2, nilai signifikansi sebesar 0,051 lebih besar dari 0,05 (sig. $=0,051>0,05)$, hal ini menunjukkan bahwa variabel ROA, ROE, NPM dan harga saham berdistribusi normal.

Tabel 3.

Hasil Uji Autokorelasi

\begin{tabular}{llrrrrr}
\hline Model & $\mathbf{R}$ & R Square & $\begin{array}{l}\text { Adjusted R } \\
\text { Square }\end{array}$ & $\begin{array}{l}\text { Std. Error of the } \\
\text { Estimate }\end{array}$ & $\begin{array}{l}\text { Durbin- } \\
\text { Watson }\end{array}$ \\
\hline 1 & $0,512^{\mathrm{a}}$ & 0,262 & 0,238 & & 0,89829 & 2,036 \\
\hline
\end{tabular}

Sumber: Data Sekunder diolah, 2018

Hasil analisis yang telah disajikan pada Tabel 3, nilai D-W sebesar 2,036 dengan $\mathrm{N}=96, \mathrm{k}=3$, maka dL sebesar 1,6063 dan dU sebesar 1,7335 (dari tabel DW dengan $\alpha=5 \%$ ). Nilai dL dan dU diperoleh dari tabel D-W dengan sampel sebanyak 96 dan variabel bebas sebanyak 3, yaitu ROA, ROE, dan NPM. Diketahui 4-dU sebesar 2,2665 (4-1,7335). Nilai D-W sebesar 2,036 berada diantara nilai dL dan 4-dU $(1,6063<2,036<2,2665)$, maka tidak terjadi autokorelasi antar variabel bebas.

Tabel 4.

Hasil Uji Multikolenearitas

\begin{tabular}{llrrr}
\hline Model & \multicolumn{3}{c}{$\begin{array}{l}\text { Colinearity Statistics } \\
\text { Tolerance }\end{array}$} \\
\hline 1 & & 0,238 & 4,206 \\
& ROA & 0,237 & 4,226 \\
& ROE & 0,987 & 1,013 \\
\hline
\end{tabular}

Sumber: Data Sekunder diolah, 2018

Berdasarkan hasil analisis yang telah disajikan pada Tabel 4 dapat diketahui bahwa nilai tolerance dari ketiga variabel bebas lebih besar dari 0,10 yaitu ROA sebesar 0,238, ROE sebesar 0,237 dan NPM sebesar 0,987. Nilai VIF dari ketiga variabel kurang dari 10 yaitu ROA sebesar 4,206, ROE sebesar 4,226 dan NPM sebesar 1,013. Hal ini menunjukkan bahwa tidak terjadi multikolenearitas dari ketiga variabel bebas.

Tabel 5.

Hasil Uji Heterokedastisitas

\begin{tabular}{|c|c|c|c|c|c|c|}
\hline \multirow{2}{*}{\multicolumn{2}{|c|}{ Model }} & \multicolumn{2}{|c|}{$\begin{array}{l}\text { Unstandardized } \\
\text { Coefficients }\end{array}$} & \multirow{2}{*}{$\begin{array}{c}\text { Standardized } \\
\text { Coefficients } \\
\text { Beta }\end{array}$} & \multirow[b]{2}{*}{$T$} & \multirow[b]{2}{*}{ Sig. } \\
\hline & & B & Std. Eror & & & \\
\hline \multirow[t]{4}{*}{1} & (Constant) & 0,768 & 0,120 & & 0,389 & 0,000 \\
\hline & ROA & 0,026 & 0,014 & 0,395 & 1,886 & 0,062 \\
\hline & ROE & $-0,007$ & 0,004 & $-0,335$ & $-1,591$ & 0,115 \\
\hline & NPM & 0,002 & 0,006 & 0,031 & 0,304 & 0,762 \\
\hline
\end{tabular}

Sumber: Data Sekunder diolah, 2018

Hasil analisis yang disajikan pada Tabel 5. dimana nilai signifikansi ketiga variabel bebas lebih besar dari 0,05, yaitu ROA sebesar 0,062, ROE sebesar 0,115 
dan NPM sebesar 0,762. Hal ini menunjukkan bahwa tidak terjadinya heteroskedastisitas pada ketiga variabel bebas.

Tabel 6.

Hasil Analisis Regresi Linier Berganda

\begin{tabular}{|c|c|c|c|c|c|c|}
\hline & \multirow[b]{2}{*}{ Model } & \multicolumn{2}{|c|}{ Unstandardized Coefficients } & \multirow{2}{*}{$\begin{array}{c}\text { Standardized } \\
\text { Coefficients } \\
\text { Beta }\end{array}$} & \multirow{2}{*}{$\mathbf{T}$} & \multirow{2}{*}{ Sig. } \\
\hline & & B & Std. Eror & & & \\
\hline \multirow[t]{4}{*}{1} & (Constant) & 7,775 & 0,217 & & 35,751 & 0,000 \\
\hline & ROA & 0,004 & 0,025 & 0,027 & 0,148 & 0,883 \\
\hline & ROE & 0,019 & 0,008 & 0,430 & 2,337 & 0,022 \\
\hline & NPM & 0,022 & 0,010 & 0,192 & 2,129 & 0,036 \\
\hline
\end{tabular}

Sumber: Data Sekunder diolah, 2018

Tabel 6. di atas, diperoleh perhitungan regresi linier, diketahui hubungan antara variabel independen dan variabel dependen yang dapat dijelaskan sebagai berikut:

$$
\mathrm{Y}=7,775+0,004 \mathrm{X}_{1}+0,019 \mathrm{X}_{2}+0,022 \mathrm{X}_{3}
$$

Koefisien regresi menunjukkan apabila tidak terdapat variabel $\mathrm{X}_{1}, \mathrm{X}_{2}, \mathrm{X}_{3}$ maka harga saham mengelami kenaikan sebesar 7,775 rupiah (Rp.). Koefisien regresi ROA $\left(\mathrm{X}_{1}\right)$ sebesar 0,004 menunjukkan setiap penambahan variabel $\mathrm{X}_{1}$ sebesar 1 persen (\%), maka harga saham akan mengalami kenaikan sebesar 0,004 rupiah (Rp.) dengan asumsi ceteris paribus. Koefisien regresi ROE $\left(\mathrm{X}_{2}\right)$ sebesar 0,019 menunjukkan bahwa setiap penambahan variabel $\mathrm{X}_{2}$ sebesar 1 persen $(\%)$, maka harga saham akan mengalami kenaikan sebesar 0,019 rupiah (Rp.) dengan asumsi ceteris paribus. Koefisien regresi NPM $\left(\mathrm{X}_{3}\right)$ sebesar 0,022 menunjukkan bahwa setiap penambahan variabel $\mathrm{X}_{3}$ sebesar 1 persen (\%), maka harga saham akan mengalami kenaikan sebesar 0,022 rupiah (Rp.) dengan asumsi ceteris paribus.

Tabel 7.

Hasil Uji Signifikansi Simultan (Uji Statistik F)

\begin{tabular}{llcrrrl}
\hline & Model & Sum of Squares & \multicolumn{1}{c}{ Df } & Mean Square & F & Sig. \\
\hline 1 & Regression & 26,376 & 9 & 8,792 & 10,895 & $0,000^{\mathrm{a}}$ \\
& Residual & 74,238 & 92 & 0,807 & & \\
& Total & 100,613 & 95 & & & \\
\hline
\end{tabular}

Sumber: Data Sekunder diolah, 2018

Hasil yang disajikan pada Tabel 7. model regresi memiliki nilai signifikansi sebesar 0,000 yaitu kurang dari 0,05 $(0,000<0,05)$. Maka variabel ROA, ROE, dan NPM berpengaruh signifikan secara simultan terhadap harga saham.

Berdasarkan Tabel 8. nilai $\mathrm{R}^{2}=0,262$ maka model penelitian ini dapat menjelaskan variabel harga saham sebesar 26,2 persen (\%) dan 73,8 persennya dijelaskan oleh faktor-faktor di luar model. 
Tabel 8.

Hasil Uji Koefisien Determinasi $\left(\mathbf{R}^{2}\right)$

\begin{tabular}{|c|c|c|c|c|c|}
\hline Model & $\mathrm{R}$ & R Square & $\begin{array}{l}\text { Adjusted R } \\
\text { Square }\end{array}$ & $\begin{array}{l}\text { Std. Error of the } \\
\text { Estimate }\end{array}$ & $\begin{array}{l}\text { Durbin- } \\
\text { Watson }\end{array}$ \\
\hline 1 & $0,512^{\mathrm{a}}$ & 0,262 & 0,238 & 0,89829 & 2,036 \\
\hline
\end{tabular}

Sumber: Data Sekunder diolah, 2018

Tabel 9.

Hasil Uji Signifikansi Parameter Individual (Uji Statistik t)

\begin{tabular}{|c|c|c|c|c|c|c|}
\hline & \multirow[b]{2}{*}{ Model } & \multicolumn{2}{|c|}{ Unstandardized Coefficients } & \multirow{2}{*}{$\begin{array}{c}\text { Standardized } \\
\text { Coefficients } \\
\text { Beta }\end{array}$} & \multirow[t]{2}{*}{$\mathbf{T}$} & \multirow[t]{2}{*}{ Sig. } \\
\hline & & B & Std. Eror & & & \\
\hline \multirow[t]{4}{*}{1} & (Constant) & 7,775 & 0,217 & & 35,751 & 0,000 \\
\hline & ROA & 0,004 & 0,025 & 0,027 & 0,148 & 0,883 \\
\hline & ROE & 0,019 & 0,008 & 0,430 & 2,337 & 0,022 \\
\hline & NPM & 0,022 & 0,010 & 0,192 & 2,129 & 0,036 \\
\hline
\end{tabular}

Variabel ROA memiliki nilai signifikansi sebesar 0,883 yaitu lebih besar dari 0,05 (sig. $=0,883>0,05)$ serta memiliki nilai B pada kolom unstandardized coefficients sebesar 0,004 . Hal ini berarti ROA memiliki pengaruh tidak signifikan terhadap harga saham. Nilai B sebesar 0,004 menggambarkan bahwa, apabila ROA meningkat sebesar 1 persen (\%), maka harga saham akan meningkat sebesar 0,004 rupiah (Rp.) dengan asumsi ceteris paribus.

Variabel ROE memiliki nilai signifikansi sebesar 0,022 yaitu lebih kecil dari $0,05$ (sig. $=0,022<0,05)$ serta memiliki nilai $\mathrm{B}$ pada kolom unstandardized coefficients sebesar 0,019. Hal ini berarti ROE memiliki pengaruh positif signifikan terhadap harga saham. Nilai B sebesar 0,019 menggambarkan bahwa, apabila ROE meningkat sebesar 1 persen (\%), maka harga saham akan meningkat sebesar 0,019 rupiah (Rp.) dengan asumsi ceteris paribus.

Variabel NPM memiliki nilai signifikansi sebesar 0,036 yaitu lebih kecil dari 0,05 (sig. $=0,036<0,05)$ serta memiliki nilai B pada kolom unstandardized coefficients sebesar 0,022. Hal ini berarti NPM memiliki pengaruh positif signifikan terhadap harga saham. Nilai B sebesar 0,022 menggambarkan bahwa, apabila NPM meningkat sebesar 1 persen (\%), maka harga saham akan meningkat sebesar 0,022 rupiah (Rp.) dengan asumsi ceteris paribus.

Hasil analisis pada penelitian ini menunjukkan nilai signifikansi sebesar 0,883 yaitu lebih besar dari 0,05 (sig. $=0,883>0,05$ ) serta memiliki nilai B sebesar 0,004. Hal ini berarti ROA memiliki pengaruh tidak signifikan terhadap harga saham. Berdasarkan hasil tersebut, maka hipotesis pertama yang menyatakan ROA berpengaruh positif signifikan terhadap harga saham ditolak.

ROA yaitu rasio untuk mengukur tingkat profitabilitas perusahaan. ROA mencerminkan seberapa efisien perusahaan dalam menggunakan asetnya dalam menghasilkan laba. Aset merupakan keseluruhan harta perusahaan, yaitu modal sendiri dan modal asing yang menjadi aktiva perusahaan untuk kelangsungan hidup perusahaan. Modal asing memiliki risiko yang tinggi, karena perusahaan menghadapi risiko perubahan kurs/nilai tukar yang akan mempengaruhi dalam 
pembayaran utang. Pelemahan mata uang domestik akan meningkatkan beban pembayaran utang dan mengurangi profitabilitas perusahaan.

Hal ini juga bisa disebabkan oleh investor yang tidak hanya melihat kemampuan dari dalam perusahaan saat menghasilkan keuntungan tetapi juga melihat risiko dari luar perusahaan. Risiko dari luar perusahaan misalnya politik, inflasi, kenaikan tarif, hingga perubahan kebijakan ekonomi Egam, Ilat, \& Pangerapan (2017).

Hasil penelitian ini sesuai dengan penelitian yang dilakukan Rorong et al. (2017), Tamuntuan (2015), Idawati \& Wahyudi (2015), Hutabarat \& Flora (2015) serta Haryuningputri \& Widyarti (2012) dimana ROA berpengaruh tidak signifikan terhadap harga saham.

Hasil analisis pada penelitian ini menunjukkan nilai signifikansi ROE sebesar 0,022 yaitu lebih kecil dari 0,05 (sig. $=0,022<0,05)$ serta memiliki nilai B sebesar 0,019. Hal ini berarti ROE memiliki pengaruh positif signifikan terhadap harga saham. Berdasarkan hasil tersebut, maka hipotesis kedua yang menyatakan ROE berpengaruh positif signifikan terhadap harga saham diterima. Semakin meningkatnya ROE pada perusahaan LQ-45 2014-2017 sebesar 1 persen (\%), maka harga saham akan meningkat sebesar 0,019 rupiah (Rp.).

ROE semakin tinggi, berarti kinerja perusahaan dalam mengelola modalnya untuk menghasilkan keuntungan bagi para pemegang saham semakin baik. Perusahaan dapat menggunakan modal dari para pemegang saham secara efektif dan efisien untuk memperoleh laba. Hasil penelitian ini sesuai dengan penelitian yang dilakukan oleh Sahroni et al. (2017), Kamar (2017), Manoppo (2015), Mussalamah \& Isa (2015), Talamati Pangemanan (2015), Purnamasari (2015), Febriyanto \& Nurwiyanta (2014), Hutami (2012) serta Nurfadillah (2011).

Hasil analisis pada penelitian ini menunjukkan nilai signifikansi NPM sebesar 0,036 yaitu lebih kecil dari $0,05(\mathrm{sig} .=0,036<0,05)$ serta memiliki nilai B sebesar 0,022. Hal ini berarti NPM memiliki pengaruh positif signifikan terhadap harga saham. Berdasarkan hasil tersebut, maka hipotesis ketiga yang menyatakan NPM berpengaruh positif signifikan terhadap harga saham diterima. Semakin meningkatnya NPM pada perusahaan LQ-45 2014-2017 sebesar 1 persen (\%), maka harga saham akan meningkat sebesar 0,022 rupiah (Rp.).

NPM yaitu perbandingan antara laba bersih dengan penjualan. Semakin tinggi NPM, semakin produktif perusahaan sehingga akan meningkatkan kepercayaan investor. Mengetahui nilai NPM, investor dapat menilai profitable perusahaan (May, 2011: p. 35). Semakin tinggi nilai NPM maka semakin tinggi harga saham. Semakin rendah nilai NPM maka harga saham akan semakin rendah. Hasil penelitian ini sesuai dengan penelitian yang dilakukan oleh Anggadini \& Tarsiah (2017), Rimbani (2016), Banchuenvijit (2016), Darnita (2013), serta Hutami (2012).

Berdasarkan penelitian ini diketahui bahwa secara teoritis, hasil penelitian ini sesuai dengan teori yang ada sebelumnya. Penelitian ini diharapkan mampu memberikan kontribusi empiris tentang pengaruh rasio profitabilitas terhadap harga saham perusahaan LQ-45 bagi pengembangan ilmu manajemen keuangan. Implikasi teoritis untuk penelitian selanjutnya bagi para akademis yang tertarik tentang topik pengaruh ROE, dan NPM terhadap harga saham penelitian ini dapat 
dikembangkan dengan menambahkan rentan periode waktu penelitian dan menambahkan jumlah sampel sehingga bisa dihasilkan kesimpulan yang lebih valid.

Implikasi praktis dalam penelitian ini menegaskan bahwa variabel ROE, dan NPM mempunyai pengaruh yang signifikan terhadap harga saham. Investor sebaiknya memperhatikan informasi-informasi yang dikeluarkan oleh perusahaan yaitu ROE, dan NPM karena informasi tersebut berpengaruh terhadap harga saham dan agar investor dapat mengambil keputusan yang tepat dalam berinvestasi pada perusahaan LQ-45. Investor harus mempertimbangkan rasio keuangan lainnya saat melakukan analisis fundamental perusahaan serta faktor lain diluar kebijakan perusahaan seperti kondisi pasar yang terjadi serta faktorfaktor eksternal yang lain karena hal ini secara tidak langsung akan mempengaruhi keuntungan yang diperoleh didalam melakukan investasi.

\section{SIMPULAN}

Hasil analisis menunjukkan bahwa ROA tidak berpengaruh signifikan terhadap harga saham pada perusahaan LQ-45 periode 2014-2017. ROE berpengaruh positif signifikan terhadap harga saham pada perusahaan LQ-45 periode 2014-2017. NPM berpengaruh positif signifikan terhadap harga saham pada perusahaan LQ-45 periode 2014-2017.

Bagi perusahaan, untuk menarik minat investor dalam rangka memobilisasi dana, perusahaan perlu melakukan pengambilan kebijakan finansial. Perusahaan hendaknya meningkatkan kinerja perusahaan tiap tahunnya agar mampu bersaing dalam memperoleh kepercayaan dari investor sehingga memudahkan untuk memperoleh modal. Peningkatan kinerja dilakukan guna meningkatkan kinerja perusahaan melalui usaha meningkatkan rasio-rasio keuangan seperti ROE, dan NPM serta memberikan informasi-informasi yang lebih jelas sehingga bisa dimanfaatkan investor untuk dijadikan pedoman dalam pengambilan keputusan investasinya.

Hasil penelitian ini menegaskan bahwa variabel ROE, dan NPM mempunyai pengaruh yang signifikan terhadap harga saham. Investor sebaiknya memperhatikan informasi-informasi yang dikeluarkan oleh perusahaan yaitu ROE, dan NPM karena informasi tersebut berpengaruh terhadap harga saham dan agar investor dapat mengambil keputusan yang tepat dalam berinvestasi pada perusahaan LQ-45. Investor juga harus mempertimbangkan rasio-rasio keuangan yang lainnya dalam melakukan analisis fundamental terhadap perusahaan serta faktor lain diluar kebijakan perusahaan seperti kondisi pasar yang terjadi serta faktor-faktor eksternal yang lain karena hal ini secara tidak langsung akan mempengaruhi keuntungan yang diperoleh didalam melakukan investasi.

Hasil penelitian menunjukkan adanya pengaruh yang signifikan dari ROE, dan NPM terhadap harga saham. Koefisien determinasi sebesar 0,262, maka model penelitian ini dapat menjelaskan variabel harga saham sebesar 26,2 persen (\%) dan 73,8 persennya dijelaskan oleh faktor-faktor di luar model. Penelitian selanjutnya hendaknya mempertimbangkan penambahan variabel-variabel lain yang mempengaruhi harga saham perusahaan-perusahaan yang ada di perusahaan 
LQ-45 serta mempertimbangkan pula faktor makro ekonomi seperti inflasi, tingkat suku bunga, kebijakan-kebijakan pemerintah, jumlah uang beredar dan faktor ekonomi lainnya yang diperkirakan dapat mempengaruhi harga saham.

\section{REFERENSI}

Amanah, R., Atmanto, D., \& Azizah, D. F. (2014). Pengaruh Rasio Likuiditas dan Rasio Profitabilitas Terhadap Harga Saham. Jurnal Administrasi Bisnis (JAB), 12(1), 1-10. Retrieved from https://media.neliti.com/ media/publications/83167-ID-pengaruh-rasio-likuiditas-dan-rasio-prof.pdf

Anggadini, S. D., \& Tarsiah, E. (2017). The Influence of Net Profit Margin And Current Ratio. Jurnal Riset Akuntansi, 9(2), 37-43. Retrieved from https://ojs.unikom.ac.id/index.php/jira/article/view/539

Banchuenvijit, W. (2016). Financial Ratios And Stock Prices: Evidence From The Agriculture Firms Listed on The Stock Exchange of Thailand. International Journal of Business and Economics, 8(1), 21-29. Retrieved from http://utcc2.utcc.ac.th/utccijbe/_uploads/UTCC Vol8 Cover December-2016Wanrapee B.pdf

Brigham, E. F., \& Houston, J. F. (2011). Dasar-Dasar Manajemen Keuangan Buku 2. Jakarta: Salemba Empat.

Darmadji, T. (2006). Pasar Modal Indonesia. Jakarta: Salemba Empat.

Darnita, E. (2013). Analisis Pengaruh Return On Assets (ROA), Return On Equity (ROE), Net Profit Margin (NPM) Dan Earning Per Share (EPS) Terhadap Harga Saham (Studi Pada Perusahaan Food Dan Beverages Yang Terdaftar Di Bursa Efek Indonesia (BEI) Pada Tahun 2008-2012). Universitas Dian Duswantoro Semarang. Retrieved from http://eprints.dinus.ac.id/8813/1/ jurnal_13597.pdf

Egam, G. E. Y., Ilat, V., \& Pangerapan, S. (2017). Pengaruh Return On Asset (ROA), Return On Equity (ROE), Net Profit Margin (NPM), Dan Earning Per Share (EPS) Terhadap Harga Saham Perusahaan Yang Tergabung Dalam Indeks LQ45 DI BURSA EFEK INDONESIA PERIODE 2013-2015. Jurnal $E M B A$, 5(1), 105-114. Retrieved from https://ejournal.unsrat.ac.id/index. php/emba/article/view/15455/14998

Febriyanto, F. C., \& Nurwiyanta. (2014). Pengaruh Return On Equity (ROE), Return On Assets (ROA), Dan Net Profit Margin (NPM) Terhadap Harga Saham Pada Sektor Real Estate And Property Di Bursa Efek Indonesia Periode 2008-2011. Jurnal Bisnis Dan Ekonomi, 5(1), 19-30. Retrieved from http://jurnalefektif.janabadra.ac.id/wp-content/uploads/2015/11/Efektif-Juni2014_2.pdf 
Ghozali, I. (2016). Aplikasi Analisis Multivariet Dengan Program SPSS. Semarang: Badan Penerbit Universitas Diponegoro.

Hartono, J. (2009). Teori Portofolio dan Analisis Investasi. (6, Ed.). Yogyakarta: BPFE.

Hartono, J. (2016). Teori Portofolio dan Analisis Investasi (10th ed.). Yogyakarta: BPFE.

Haryuningputri, M., \& Widyarti, E. T. (2012). Pengaruh Rasio Profitabilitas Dan Eva Terhadap Harga Saham Pada Sektor Industri Manufaktur Di BEI Tahun 2007-2010. Diponegoro Journal of Management, 1(2), 67-79. Retrieved from https://ejournal3.undip.ac.id/index.php/djom/article/view/772/747

Hunjra, A. I., Ijaz, M. S., Chani, M. I., Hassan, S. ul, \& Mustafa, U. (2014). Impact of Dividend Policy, Earning per Share, Return on Equity, Profit After Tax on Stock Prices. Much Personal RePEc Archive, 2(3), 109-115. Retrieved from https://mpra.ub.uni-muenchen.de/60793/1/MPRA_paper_ 60793.pdf

Hutabarat, F. M., \& Flora, J. (2015). Exploring Factors Affecting Stock Price of Indonesia State Owned Bank Listed at Indonesia Stock Exchange. Academic Research International, 6(3), 42-52. Retrieved from http://www.savap. org.pk/journals/ARInt./Vol.6(3)/2015(6.3-05).pdf

Hutami, R. P. (2012). Pengaruh Dividend Per Share, Return On Equity Dan Net Profit Margin Terhadap Harga Saham Perusahaan Industri Manufaktur Yang Tercatat Di Bursa Efek Indonesia Periode 2006-2010. Jurnal Nominal, 1(1), 104-123. Retrieved from https://media.neliti.com/media/publications/ 191438-ID-none.pdf

Hutapea, A. W., Saerang, I. S., \& Tulung, J. E. (2017). Pengaruh Return On Assets, Net Profit Margin, Debt To Equity Ratio, Dan Total Assets Turnover Terhadap Harga Saham Industri Otomotif Dan Komponen Yang Terdaftar Di Bursa Efek Indonesia. Jurnal EMBA, 5(2), 541-551. Retrieved from https://media.neliti.com/media/publications/141125-ID-none.pdf

Idawati, W., \& Wahyudi, A. (2015). Effect of Earning Per Shares ( EPS ) and Return On Assets ( ROA ) against Share Price on Coal Mining Company Listed in Indonesia Stock Exchange. Journal of Resources Developement and Management, 7(1), 79-92. Retrieved from https://www.iiste.org/ Journals/index.php/JRDM/article/view/21754/21882

Kabajeh, M. A. M., Nu'aimat, S. M. A. Al, \& Dahmash, F. N. (2012). The Relationship Between the ROA, ROE and ROI Ratios with Jordanian 
Insurance Public Companies Market Share Prices. International Journal of Humanities and Social Science, 2(11), 115-120. Retrieved from http://www.ijhssnet.com/journals/Vol_2_No_11_June_2012/12.pdf

Kamar, K. (2017). Analysis of the Effect of Return on Equity ( Roe ) and Debt to Equity Ratio ( Der ) On Stock Price on Cement Industry Listed In Indonesia Stock Exchange ( Idx ) In the Year of 2011-2015. IOSR Journal of Business and Management (IOSR-JBM), 19(5), 66-76. https://doi.org/10.9790/487X1905036676

Kasmir. (2012). Analisis Laporan Keuangan. Jakarta: PT Raja Grafindo Persada.

Kundiman, A., \& Hakim, L. (2016). Pengaruh Current Ratio, Debt To Equity Ratio, Return On Asset, Return On Equity Terhadap Harga Saham Pada Indeks LQ 45 Di BEI Periode 2010-2014. Among Makarti, 9(18), 80-98. Retrieved from http://jurnal.stieama.ac.id/index.php/ama/article/viewFile/ $140 / 131$

Manoppo, C. P. (2015). The Influence of ROA, ROE, ROS, And EPS On Stock Price. Jurnal EMBA, 3(4), 691-697. Retrieved from https:// media.neliti.com/media/publications/2869-EN-the-influence-of-roa-roe-rosand-eps-on-stock-price.pdf

May, E. (2011). Smart Traders Not Gamblers. Jakarta: PT Gramedia Pustaka Utama.

Mogonta, K., \& Pandowo, M. (2016). Analyzing The Effect of Return On Assets, Return On Equity And Earnings Per Share on Market Share Price: A Study of LQ-45 Mining Companies Listed On Indonesia Stock Exchange. Jurnal $E M B A, 4(2)$, 703-713. Retrieved from https://ejournal.unsrat.ac.id/ index.php/emba/article/view/13150/12735

Murniati, S. (2016). Effect Of Capital Structure, Company Size And Profitability on the Stock Price of Food And Beverage Companies Listed on the Indonesia Stock Exchange. Information Management And Business Review, 8(1), 2329. Retrieved from https://ifrnd.org/journal/index.php/imbr/article/view/1192

Mussalamah, A. D. M., \& Isa, M. (2015). Pengaruh Earning Per Share (EPS), Debt To Equity Ratio (DER) Dan Return On Equity (ROE) Terhadap Harga Saham. Jurnal Management Dan Bisnis, 19(2), 189-195. Retrieved from http://journals.ums.ac.id/index.php/benefit/article/view/2319/1581

Noor, M. I., \& Rosyid, P. I. (2018). Effect of Capital Adequacy Ratio (CAR), Loan to Deposit Ratio (LDR) and Return on Equity (ROE) on Share Price PT Bank Danamon Indonesia TBK. Center for Promiting Education and Research (CPER) USA, 4(1), 87-101. Retrieved from https://papers.ssrn. com/sol3/papers.cfm?abstract_id=3110489 
Nurfadillah, M. (2011). Analisis Pengaruh Earning Per Share, Debt to Equity Ratio dan Return On Equity Terhadap Harga Saham PT Unilever Indonesia Tbk. Jurnal Manajemen Dan Akuntansi, 12(1), 45-50. Retrieved from http://journal.stiei-kayutangi-bjm.ac.id/index.php/jma/article/view/32/30

Perdana, R. A. P., Darminto, \& Sudjana, N. (2013). Pengaruh Return On Equity (ROE), Earning Per Share (EPS), Dan Debt Equity Ratio (DER) Terhadap Harga Saham. Jurnal Administrasi Bisnis (JAB), 2(1), 128-137. Retrieved from http://administrasibisnis.studentjournal.ub.ac.id/index.php/jab/article /view/82/1647

Purnamasari, D. (2015). The Effect of Changes in Return on Assets , Return on Equity, and Economic Value Added to the Stock Price Changes and Its Impact on Earnings Per Share. Research Journal of Finance and Accounting, 6(6), 80-90. Retrieved from https://www.iiste.org/Journals/index.php/ RJFA/article/view/21162/21386

Rahmadewi, P. W., \& Abundanti, N. (2018). Pengaruh EPS, PER, CR Dan ROE Terhadap Harga Saham Di Bursa Efek Indonesia. E-Jurnal, 7(4), 2106-2133. https://doi.org/https://doi.org/10.24843/EJMUNUD.2018.v7.i04.p14

Rahyuda, I. K. (2017). Metode Penelitian Bisnis (Revisi). Denpasar: Udayana University Press.

Rimbani, R. P. (2016). Analisis Pengaruh ROE, EPS, PBV, DER dan NPM Terhadap Harga Saham Pada Perusahaan Real Estate dan Property di Bursa Efek Indonesia Periode 2011-2013. Jurnal Bisnis Dan Manajemen, 53(12), 182-228. Retrieved from https://media.neliti.com/media/publications/ 254641-none-1206bc2a.pdf

Rorong, A., Saerang, I. S., \& Untu, V. (2017). Analisis Risiko Sistematis dan Faktor Fundamental Terhadap Harga Saham Pada Perusahaan Sektor Properi Yang Terdaftar di Bursa Efek indonesia. Jurnal EMBA, 5(3), 4015-4025. Retrieved from https://ejournal.unsrat.ac.id/index.php/emba/article/viewFile $/ 18285 / 18197$

Sahroni, Zulfitra, Sampurnaningsih, S. R., \& Hanifah, A. (2017). Determinant of Stock Price: A Empirical Study at State Owned Enterprises in Indonesia. International Journal of Applied Business and Economic Research, 15(20), 1-10. Retrieved from https://tixpdf.com/determinant-of-stock-price-aempirical-study-at-state-owned-.html

Sugiyono. (2013). Metode Penelitian Bisnis. Yogyakarta: Alfabeta.

Talamati, M. R., \& Pangemanan, S. S. (2015). The Effect of Earnings Per Share (EPS) \& Return On Equity (ROE) On Stock Price Of Banking Compay Listed In Indonesia Stock Exchange (IDX) 2010-2014. Jurnal EMBA, 3(2), 
2010-2014.

Retrieved

from

https://www.google.com/url?sa=t\&rct=j\&q=\&esrc=s\&source=web\&cd=1\&v ed=2ahUKEwjSvrWKv8ngAhXGT30KHXNBCBcQFjAAegQIARAC\&url= https $\% 3 \mathrm{~A} \% 2 \mathrm{~F} \% 2$ Fejournal.unsrat.ac.id $\% 2$ Findex.php\%2Fjbie $\% 2$ Farticle $\% 2$ Fdownload\%2F9855\%2F9441\&usg=AOvVaw1BtEehm95kNzlzM16u1tqS

Tamuntuan, U. (2015). Analysing The Effect Of Return On Equity, Return On Assets And Earnings Per Share TOward Share Prices: An Empirical Study Of Food And Beverage Companies Listed On Indonesia Stock Exchange. Jurnal Berkala Ilmiah Efisiensi, 15(05), 446-457. Retrieved from https://media.neliti.com/media/publications/2662-EN-the-effect-of-earningsper-share-eps-return-on-equity-roe-on-stock-price-of-bank.pdf

Wiagustini, N. L. P. (2014). Manajemen Keuangan (1st ed.). Denpasar: Udayana University Press. 